\section{BESZÁMOLÓ A MABISZ 2019. NOVEMBER 21-I KONFERENCIÁJÁRÓL}

Lencsés Katalin (Magyar Biztositók Szövetsége ), katalin.lencses@mabisz.hu

\section{ÖSSZEFOGLALÓ}

A MABISZ 2019 novemberében tartotta X. nemzetközi konferenciáját. Az idei rendezvény középpontjában a pozitív ügyfélélmény volt. Jelen cikk erről az eseményről ad összefoglalót.

\section{SUMMARY}

The Association of Hungarian Insurance Companies (MABISZ) held its 10th conference in November 2019. This year the event focused on positive customer experience. This article gives the summary of the conference.

Kulcsszavak: biztosítás, konferencia, ügyfélélmény

Keywords: conference, customer experience, insurance

JEL: G22

DOI: 10.18530/BK.2020.1-2.94

http://dx.doi.org/10.18530/BK.2020.1-2.94
A Magyar Biztosítók Szövetsége 2019. november 21-én tartotta X. konferenciáját a Corinthia Budapest Hotelben. A biztosítási szektor legnagyobb konferenciája ismét kiváló alkalmat jelentett a biztosítók, a velük együttmüködő vállalkozások, a szabályozói és felügyeleti döntéshozók képviselői számára a magas szintű szakmai eszmecserére. A rendezvény középpontjában ezúttal a pozitív ügyfélélmény állt.

A konferenciát a MABISZ főtitkára, Dr. Molnos Dániel nyitotta meg, kiemelve azt, hogy a biztosítók fontosnak tartják a kiszolgálás színvonalának állandó javítását. A szövetség vonatkozásában példaként a MABISZ ügyfélszolgálat és az E-kárbejelentő került megemlítésre.

Az első előadó Varga Mihály, pénzügyminiszter, miniszterelnök-helyettes volt. Előadását azzal kezdte, hogy az Európai Unióban a befektetések 58 százalékát adják a biztosítók befektetései. A szakmának Magyarországon is fontos szerepe van, habár a biztosítási dijbevétel még több helyen nem érte el az uniós átlagot (életbiztosítás, egészségbiztosítás). A kormány célja a win-win helyzet előállítása, amit részben a pénzügyi tudatosság erősítésével kívánnak elérni. Ennek a törekvésnek már vannak eredményei is. Az új szerződéskötések száma nőtt, ahogy a dijbbevétel is, ami 2018 végére meghaladta az 1000 milliárdot. Javult a szektor jövedelmezősége, a biztosítói befektetésekből 1400 milliárd Ft állampapírban van.

A magyar gazdaság első féléves növekedése 5 százalékos volt, ami EU szinten jónak tekinthetö, és a visegrádi országokban is középmezőnynek számít. A foglalkoztatási ráta 70,3 százalék, ugyanakkor itt még van tartalék. A megtakarítások növekedése azt mutatja, hogy valóban van reálbér-növekedés.

\section{Nincs arra szándék, hogy a nyugdíjtermékekre vonatkozó} kedvezményeket szükítsẹk.

A jogszabályi környezetre áttérve elhangzott, hogy 2018-ban megtörtént az európai IDD szabályozás átültetése, melynek kapcsán az ügyfél-tájékoztatás követelményei szigorodtak. Jelenleg a pénzmosásról szóló jogszabály módosítása van kézben, ami már a VI. európai irányelv átültetését készíti elő. A pénzügyminiszter azt is elmondta, hogy az Európai Bizottság megkezdte a Szolvencia II szabályozás rutinszerű felülvizsgálatát.

A fejlődési lehetőségekre áttérve elhangzott, hogy 2017-ben elfogadásra került a lakosság pénzügyi tudatosságának fejlesztésére irányuló stratégia, nem függetlenül attól, hogy a lakosságnál 6500 milliárd Ft van készpénzben, amit a döntéshozók vissza szeretnének csatornázni a gazdaságba. Nincs arra szándék, hogy a nyugdíjtermékekre vonatkozó kedvezményeket szűkítsék, várhatóan a jövőben is nőni fog az igény a nyugdíj- és egészségbiztosítások iránt. A Pénzhét rendezvény az iskolás korosztály körében népszerüsíti a pénzügyi kultúrát, ennek kapcsán a pénzügyminiszter megköszönte a MABISZ-nak, hogy az oktatási anyag elkészítésében részt vett.

Az előadás végén megtudhattuk, hogy a pénzügyi kormányzat recesszióval nem, de gazdasági lassulással számol. Lehetnek tehát negatív hatások, amelyekre fel kell készülni. A kormány reagálva a kihívásokra az öngondoskodás erősítésében is keresi a válaszokat. 
A második előadó Erdős Mihály, a MABISZ alelnöke bemutatta a szövetség, illetve a biztosítók működéséből azokat az elemeket, melyek a pozitív ügyfélélményre irányulnak, ami a mostani konferencia fókuszában van. A digitalizált ügyfélélményt segíti a MABISZ új alkalmazása, az E-kárbejelentő, ami a kgfb-kárbejelentéseket segíti a XXI. század eszközeivel. Erről a konferencia későbbi részében további részleteket is hallhattunk.

A közelmúltban zajlott a Biztonság Hete rendezvénysorozat, amely az ORFK és a MABISZ által rendezett országos program. Az idei esemény már 25 ezer diákot ért el, és a videómegtekintések száma meghaladta a 700 ezret. Ide kapcsolódik a MABISZ fiatal generációs stratégiája is, aminek része egy esettanulmány verseny, edukációs online játék és edukációs partnerség más szervezetekkel.

A biztositók is hosszú távú feladatuknak érzik a pénzügyi és digitális kultúra fejlesztését, a papírmentes működés erősítését. Ennek kapcsán szorgalmazzák a digitális megoldásokra vonatkozó szabályok modernizálását és egységesítését, a papíralapú igazolások helyett a digitális alternatíva elfogadását, bizonyos állami nyilvántartások elektronikus, automatikus elérhetőségét, valamint azt, hogy bizonyos limit felett kötelező legyen az elektronikus úton befizetendő „sárga csekk”.

Az ügyfélélményt jelentősen rontja az az abszurd mennyiségű tájékoztatási kötelezettség, mely az életbiztosításokat terheli. A tájékoztatási kötelezettségek elsősorban EU-szintű szabályozáson alapulnak, ugyanakkor van mozgástér a hazai szabályozásban is. A MABISZ-nak erre részletesen kidolgozott javaslatai vannak, és ezek megvalósításában kéri a szövetség az MNB és a PM partnerségét.

A biztosítókba vetett bizalom az elmúlt időszakban nem változott a BIBIX index értékei szerint.

Harmadik éve a Századvég a MABISZ megbízásából a BIBIX mutatóval méri az ügyfeleknek a biztosítással való elégedettségét, és az eredményröl a szövetség az éves konferenciákon számol be. Ennek alapján a fiatalok és a képzettek ismerik a legtöbb biztosítási fajtát, jelenleg lakásbiztosítással rendelkeznek a legtöbben, és a biztosítókba vetett bizalom az elmúlt időszakban nem változott a BIBIX index értékei szerint.

A kedvező gazdasági környezetnek örül a szektor, ugyanakkor az életbiztosítási tartalékok még nem tükrözik a lehetőségeket. Habár egy éve alatt több mint 52 ezer új nyugdíjbiztosítási szerződés került megkötésre, ebben a termékben még bőven van potenciál. Ezt igyekszik kiaknázni a MABISZ immár szokásos nyugdíjbiztosítási kampánya is, ami idén új vizuális és tartalmi elemekkel bővült.

Végül szó esett a MNB fogyasztóbarát lakásbiztosításáról, mely örvendetes módon igyekszik beemelni a piaci legjobb gyakorlatokat, egységes fogalomhasználatot vezet be, és a digitalizáció irányába is tesz egy lépést. A MABISZ alelnök ennek kapcsán annyit füzött hozzá, hogy a digitalizáció mellett legalább annyira fontos a kommunikáció egyszerüsége.
A következő előadó Szeniczey Gergő, az MNB ügyvezető igazgatója volt. Nyitásként a konferencia résztvevői megtudhatták, hogy az MNB-n belül a közelmúltban lezajlott átszervezés következtében a biztosítók fogyasztóvédelmi és prudenciális felügyelete összevonásra került. A jövőbeni irányok és célok kapcsán az előadó a következőket említette meg:

- Transzparencia megkövetelése, kiemelt fókusszal az árazásra. Ennek kapcsán a TKM rendszer továbbfejlesztése, egyediesítése;

- A garanciamechanizmusok kiterjesztése;

- A gazdaságfinanszírozó szerep erősítése a háztartások megtakarításának aktivizálásával;

- Versenyképes, innovációkban gazdag, etikus piac biztosítása;

- A kgfb-piac szabályozásának újragondolása a felügyeleti tapasztalatok alapján;

- Ezt követően az előadó részletes áttekintést nyújtott a biztosítási piac fejlődéséről az elmúlt időszakban. A szektor továbbra is fejlődő pályán van, habár a hozameredmények gátolták a tartalékok bővülését. A szektor jövedelmezősége 2019-ben az előző évhez hasonlóan alakulhat, az adózott eredmény és a ROE egyaránt eléri a válság előtti szintet. Az etikus élet szabályozás profitnyomása nem látszik élesen, habár az elmúlt években főleg a nem-élet ág (kgfb) növelte az eredményt. Az eredmény összetétele változott, nagyobb lett a biztosítástechnikai eredmény.

\section{A korábbi trendet követi, hogy nő a nyugdíjbiztosítások aránya az állományon beliil.}

Stabil a szektorszintű tőkemegfelelés, az MNB volatilitási tőkepuffer ajánlás hatásos és szükséges. 2019-ben akár 1100 milliárd Ft feletti díjbevétel is várható, a TOP5 koncentráció pedig 60 százalék felett van. 2019-ben várhatóan tovább bővül a rendszeres életbiztosítási piac, ehhez mind az UL, mind a hagyományos szerződések növekedése hozzájárul. A korábbi trendet követi az is, hogy nő a nyugdíjbiztosítások aránya az állományon belül.

Két év alatt közel 3000 közvetítővel kevesebb dolgozik a piacon, és ezzel párhuzamosan az egy före eső jutalékbevétel nőtt. Eredményként könyveli el az MNB azt is, hogy 2015 óta jelentősen és tartósan sikerült csökkenteni a TKM értéket, és mérséklődtek a vagyonkezelési költségek is. Az MNB a limithatároktól megengedett eltérések indokoltságát is vizsgálja. 2018-ban és 2019-ben is emelkedett a hagyományos termékek díjbevételi aránya, az egyszeri és eseti díjbevételeknél az MNB összességében nem vár jelentős növekedést.

Áttérve a nem-élet biztosításokra, elhangzott, hogy az adóváltozás fokozta a nem-élet díjnövekedést, mivel a korábbi adóteher beépítésre került a díjakba. Továbbra is a kgfb maradt a nem-élet ág húzóereje, a második legnagyobb növekményt pedig a casco adta.

Nem-élet területen MNB-aktivitás a központi kgfb tételes adatbázis elindítása, ami a piacon és az MNB-nél lévő adatok hasznosítását jelenti. Ebből az összesített szerződés- és káradatok közzététele a biztosítók működését is könnyíteni fogja. 
Az MNB legújabb projektje a minősített fogyasztóbarát otthonbiztosítás (MFO), ami magas kockázati lefedettséget céloz meg, és kétszintű sztenderdizálást jelent. A sztenderd alapcsomag tartalmazza a kötelező elemi károkat és általános modulokat. Ezek opcionálisan kiegészíthetők további fedezetekkel, melyek tartalmukban nem, de elnevezésben sztenderdizáltak. Az új MFO termékek piacra lépése 2020 elején valósulhat meg.

A MABISZ alelnökének az előadásában már volt szó az E-Kárbejelentőről. Lengyel Sándor, a TIGRA Kft. képviseletében a technikai megvalósítás hátterét mutatta be a konferencián. Fontos szempont volt, hogy az alkalmazás trendkövetö legyen, ezért ilyen funkciók kerültek beépítésre. Ez például a telefon párosítása PIN kóddal, a fényképezés, a beépített térkép használata, a QR kód és a hangrögzítés. Következő fejlesztési lépések az automatizált feldolgozás 1-2 nap alatt, a biztosítói visszajelzések beépítése és a gyorsított kárfelmérés. Az applikáció működésével kapcsolatos statisztikát a fejlesztők folyamatosan figyelik és elemzik, a felhasználói visszajelzések gyűjtése és elemzése pedig Survey Monkey kérdőív segítségével történik. A fejlesztési folyamatba fókuszcsoport is bevonásra kerül. A QR kódok ügyfeleknek való kiküldésével az alkalmazás letöltésének száma több mint 43 ezerrel nőtt.

A kávészünetet követően Reny Vargis-Cheriyan adatelemző Londonból az ügyfélvélemény-szerzésről beszélt a szolgáltató szektorban, ezen belül is arról, hogy a mesterséges intelligencia hogyan alkalmazható a biztosítási szektorban, hogyan kapcsolódik egymáshoz a mélytanulás, a gépi tanulás és a mesterséges intelligencia. A három módszer kombinációja adja a legjobb eredményt.

Az új technológia egyaránt használható az értékesítésben, kockázatelbírálásban, kárrendezésben és adminisztrációban. Például a szelfik segíthetik az árazást, mivel az arcról visszaverődő fény mutatja az egészségi állapotot, a drónok felderíthetik a kárrendezéshez a terepet hurrikánok után. A virtuális tanácsadó szerepe egyelöre még vitatott, és lehet, nem is mindig jó a tapasztalat, de a fejlödéssel ez egyre inkább személyre szabott tud lenni.

A bemutatott TruVoice technológia a call centerbe beérkező hívások mindegyikét elemezni tudja viselkedési és érzelmi szempontból, segít gyorsan megérteni, hogy mit érez az ügyfél. Minden fogyasztói reakciót monitoroz, azt is, hogy mit mond az ügyfél, és azt is, hogy hogyan mondja, segítve ezzel az ügyfélkapcsolat javítását. Különösen hasznos ez a funkció a sérülékeny ügyfelek esetében.

A megkérdezettek gyakran megemlítették a személyes kapcsolat fontosságát, és annak gyakori hiányát a pénzügyi szolgáltatóknál.

Hídvégi Áron, a Századvég igazgatója egy telefonos módszerrel lebonyolított kutatás eredményét ismertette. Vizsgált témakörök az ügyfél-elégedettség, elkötelezettség, ügyfélélmény-összetevők és az ügyfélút voltak. Az elégedettség összehasonlításában a biztosítók a háziorvos és az autószerelő mögött, de a bank előtt végeztek 4,13-as értékeléssel az 5 fokozatú skálán. Ugyanebben a körben a biztosítók már az utolsó helyen végeztek, amikor arra a kérdésre kellett válaszolni, hogy az adott szolgáltatást mekkora valószínűséggel ajánlaná valaki barátainak vagy kollégáinak. A bizalomhiányt többek között azzal magyarázták a megkérdezettek, hogy a biztosítóval sokkal kevesebb a kapcsolat.

Az ügyfelek véleménye több szempont figyelembevételével alakul ki. Ezek a szolgáltatás minősége, a dolgozók hozzáállása, a kommunikáció/elérhetőség, illetőleg az ügyfélkapcsolat. Az egyes elemeket különböző súllyal veszik figyelembe az ügyfelek, első helyre a megbízható szolgáltatást sorolják, míg legkevésbé a korszerü digitális szolgáltatást tekintik fontosnak. Ez utóbbi mindenképpen elgondolkodtató megállapítása a felmérésnek. Fontos ugyanakkor az ügyfeleknek az érthetőség a tájékoztatásban, a segítőkészség, őszinteség, a kommunikáció és az egyéni igények megértése, ami sokaknak a biztosítási ügynökben manifesztálódik. Új elem, hogy a megkérdezettek gyakran megemlítették a személyes kapcsolat fontosságát, és annak gyakori hiányát a pénzügyi szolgáltatóknál.

A digitalizáció nem önmagában cél, az csak egy felület, segítség az ügyfél-kommunikációban, és nem tudja teljesen kivảltani a személyes kommunikációt.

A konferencia első felét a vezérigazgatói kerekasztal zárta, melynek részvevői voltak Alexander Protsenko elnök-vezérigazgató (Allianz), Almássy Gabriella igazgatósági tag (UNION), Hochmann András vezérigazgató (GRAWE), Zolnay Judit elnök-vezérigazgató (Metlife). A moderátor Lambert Gábor, a MABISZ kommunikációs vezetője volt. A kerekasztalbeszélgetés is az ügyfélélmény témáját járta körbe. Ez egy olyan kategória, amihez több területnek kell összefognia, és a brand összességét fogja majd az ügyfél értékelni. Jellemzően elvárás a gyorsaság, egyszerűség és jó szolgáltatás. A biztosítóknál jellegzetesség, hogy az ügyfél többnyire negatív élmény kapcsán találkozik a szolgáltatóval (kárt szenvedett el), és el sem tudják képzelni, hogy ez az élmény lehet pozitív is. Természetesen a kérdést az is árnyalja, hogy milyen típusú biztosításról van szó. Az életbiztosításoknál a személyes kapcsolat, a tanácsadó szerepe kulcsfontosságú. Ezért is kiemelten fontos a tanácsadók képzése, fejlesztése, illetve az edukáció, hogy pozitív asszociációkat lehessen elérni. Ez a gondolat azzal kerül kiegészítésre, hogy nem-élet területen némiképp más a helyzet. Kérdés, hogy egy egyszerűbb termék esetén egyáltalán kapcsolatba lép-e az ügyfél a biztosítóval, tehát van-e személyes tanácsadás.

A beszélgetés reflektál az előző előadásra is, miszerint az ügyfélélmény magas, míg az elköteleződés alacsony az ügyfelek részéről a biztosítás esetében. Kérdés, hogy edukációval mit lehet tenni az utóbbival szemben? Két irány van, a digitalizáció és a személyes kapcsolat, és mindkét irány egyaránt fontos. Ugyanis bizonyos termékek esetében még a fiatalok is elvárják a személyes tanácsadást. Megtakarítással kombinált életbiztosítások esetén lejáratkor csalódhat az ügyfél, el kell kerülni, hogy ilyen ügyfelek legyenek. Itt megkerülhetetlen a korrekt értékesítés szerepe, hogy az ügyfél tudja, a biztosításnak ára van.

A digitalizáció kapcsán szintén a Századvég-kutatásra történt visszautalás, miszerint a magyar ügyfél azt leértékeli. A digitalizáció nem önmagában cél, az csak egy felület, segítség 
az ügyfél-kommunikációban, és nem tudja teljesen kiváltani a személyes kommunikációt. A tanácsadást még Ázsiában is használják, nem lehet leírni ezt a csatornát. Ez a munka egyre inkább át fog alakulni coaching tevékenységgé

Az EU-s szabályozás kritikájaként elhangzott, hogy az inkább akadálya az ügyfélélménynek a túlzó tájékoztatási kötelezettségek miatt, mindazonáltal a GRAWE tájékoztatása szerint az ügyfelek szeretik a KID dokumentumot. Ez utóbbi kapcsán kibontakozott egy eszmecsere, hogyan tudná érzékelni az ügyfél azt a célt, amiért az adott jogszabály létrejött, hogy a szabályozás valójában érte született. A jogszabályalkotásból adódó túlzásokon túlmenően felmerült, hogy sokszor nem a jogi és compliance területen csúszik-e el a dolog.

Az ebédszünet előtt elhangzott még egy előadás a MABISZ esettanulmány versenyének előző évi nyertesétől, Retkes Ádámtól, melynek témája a biztosítási csalások azonosítását segítő alkalmazás. A VCU egy intelligens hitelesbeszéd-vizsgáló eszköz, ami Deep Learning technológiát használ az emberi arc elemzéséhez és értékeléséhez. Az előadás után átadásra kerültek a 2019. évi MABISZ esettanulmány verseny díjai.

A délutáni program két szekcióra vált szét, az egyik az életbiztosítások, a másik pedig a nem-életbiztosítások iránt érdeklődők számára kínált érdekességet.

\section{Nem-élet szekció}

A szekció első előadója Radnóti Tibor, a Startis cég től, aki az agilis működésről tartotta az előadását. Az agilis működés mögött a hajtóerők a gyorsan változó külső környezet, a növekvő fluktuáció, a hosszú értéklánc/távoli ügyfél és a specializáció/elidegenedés. Ez a működés nem egy fejlesztési (technikai) módszertan, hanem vállalatszervezési és munkapszichológiai válasz a nagyvállalatok növekvő tehetetlenségére, az eredményszemlélet meggyengülésére és az ügyfélközpontúság elvesztésére. Az agilitásnak különböző fokai vannak, a piramis csúcsára egy érett vállalat 4-8 év alatt juthat fel, ha nem szeretne menetközben súlyos balesetet szenvedni. Erős technológiai és szervezeti változások kellenek ehhez az evolúcióhoz.

A második előadó Jiří Fialka volt, a Deloitte képviseletében. Az előadás egy cseh ökoszisztéma tapasztalatait foglalta össze, körbejárva azt a kérdést, hogy mi lehet a mindenki által ismert klasszikus biztosítás korszerű alternatívája. Az már nemcsak egyszerűen a kockázat átvállalásáról szól, hanem a megelőzésnek, védelemnek, kockázatáthárításnak, megoldások nyújtásának és a szolgáltatásnak egyfajta kombinációjáról. Konkrét példákként az okosotthon és a kiberbiztosítások kerültek megemlítésre.

A nem-élet szekciót kerekasztal-beszélgetés zárta, melynek résztvevői voltak Gordos József, a Pénzügyminisztérium főosztályvezető helyettese, Nagy Koppány, az MNB felügyeleti igazgatója, Kaszab Attila, a K\&H Biztosító vezérigazgató helyettese és Szombat Tamás, az AEGON vezérigazgató-helyettese. A moderátor Kerékgyártó Csaba, a MABISZ fötitkárság vezetője volt.
Elsőként a kerekasztal résztvevői azt a kérdést járták körbe, hogy átveszik-e a jármügyártók a gépjárműbiztosítók szerepét. Szabályozási oldalról a minisztérium képviselője kiemelte, hogy középtávon nem várhatú ilyen jellegű változás - a kgfb területén semmiképpen sem. Meglátása szerint a biztosítási szerződési feltételekben - látva az Európai Bíróság ítéleteit - bővülni fog a kockázatok köre, valamint annak területi hatálya is. Egy bírósági ítélet szerint például a garázsban parkoló autó kigyulladt, amely autót a forgalomban részt vett járműnek minősített a bíróság. A kgfb-biztosítónak kötelező volt kifizetnie a tűz által az egyéb vagyontárgyban keletkezett kárt. Mögöttes felelősségi szabályként belép a termékfelelősség, amely alapján visszkereset keretében a jármű gyártójától lehet követelni a kifizetett kártérítési összeget. Felügyeleti oldalról ez azzal került kiegészítésre, hogy az üzemben tartói felelősség marad a meghatározó, ami alapján a biztosítók állnak helyt.

A biztosítói oldal az előtte szólókkal egyetértett, nincs itt az ideje a járműgyártók kiemelt szerepének. Casco biztosítás tekintetében ugyanakkor már ma is van néhány jármügyártmány, amelynek van casco biztosítója. Ennek kapcsán kihangsúlyozták, hogy a 15 százalékos adó miatt nagy a teher a casco biztosításon. Az MNB képviselője ezzel egyetértett, kiegészítve azzal, hogy az adó a kgfb-ben nem okoz ilyen mértékű torzulást.

A második témakör a telematikai vagy használatalapú biztosításhoz kapcsolódott, amikor a biztosított csak akkor fizet díjat, amikor ténylegesen fennáll a biztosítási esemény kockázata. Egyetértés volt abban, hogy jelentős fejlődés előtt állunk ezzel kapcsolatban. A telematika a veszélyközösség szervezési elvét befolyásolni fogja, jobban mérhetővé teszi a vezetést, mennyit, hogyan vezetnek a járművezetők. Sőt, a beszélgetés még ennél is tovább ment, az „on demand” biztosítás elterjedésével - ami ma is működik már - hosszú távon eltűnik a biztosítás olyan formában, ahogy most ismerjük.

\section{—A telematika a veszélyközösség szervezési elvét befolyásolni fogja.}

Az MNB a konferenciát megelőző napon hozta nyilvánosságra a Minősített Fogyasztóbarát Otthonbiztosítás Pályázati kiírást, melyet az MNB és a MABISZ között hónapig tartó szakmai egyeztetés előzött meg. A Pályázatra az MNB szerint azért volt szükség, mert a magyar lakásbiztosítási piacon nem megfelelő a verseny intenzitása, magas a piaci koncentráció, túl alacsonyak a kárhányadok, és nincs igazi díjverseny. Megítélésük szerint a verseny élénkítésére a Pályázat megfelelő eszköz, pozitív a tapasztalat a Minősített Fogyasztóbarát Lakáshitel alapján is. A Pályázat az alábbi alapelvekre építve került kialakításra:

- Háztartások egzisztenciális biztonságának növelése. A szolgáltatások kiterjedése minden, egzisztenciát veszélyeztető kockázatra. Szükség esetén rendkívüli eljárások alkalmazása. A díj és ellenszolgáltatás egyensúlya.

- Jó piaci gyakorlatok átvétele.

- A biztosított érték pontos meghatározása és alkalmazása a szerződés fennállása során. Alul- és túlbiztosítottság elkerülése. 
- Jól nyomon követhető, hatékony kárrendezés, igazítva az élethelyzethez. Folyamatos kommunikáció az ügyféllel.

- Régi és új ügyfelek azonos kezelése.

- Értékkövetés valós érték alapján.

- Egyszerü, közérthető szerződéses dokumentumok. Kárigény elutasítása esetén világos indokolás.

- Korszerü digitális technológiák, családbarát és zöld szempontok alkalmazása.

- A Pénzügyminisztérium szerint jelenleg nincs szabályozási feladat ebben a témában. Az MNB megköszönte a MABISZ munkáját a Pályázati kiírás egyeztetési folyamatban, és várja a biztosítók pályázatait, melyek benyújtására 2020. január 10-től van lehetőség. A biztosítók tanulmányozzák a Pályázati kiírást, s minden szempont figyelembevétele után döntenek a Pályázaton való részvételről.

\section{Élet szekció}

Az élet szekció Farkas András nyugdíjszakértő előadásával nyitott a nyugdíjtervezés kihívásairól, melyek a nyugdíjrendszer kockázataiból, az időszemlélet korlátaiból és az állam piaci megjelenéséből erednek. A demográfia öregedés problémája mindenki előtt ismert, a 65 évesnél idősebbek aránya 2041-re a mostani 18,28-ról 28 százalékra fog emelkedni. Az állam beavatkozási lehetőségei is javíthatnak vagy ronthatnak a helyzeten. Ilyen a nyugdíjkorhatár megállapítása, a valorizáció, a nyugdíjak karbantartása, a nyugdíjplafon stb. Rontják a rendszer, továbbá a kata-féle adózási lehetőségek, a minimálbéres bejelentés, a részmunkaidős foglalkoztatás, valamint az, hogy mostanra több mint 600 ezer képzett magyar tartósan külföldön dolgozik. Ennek következtében a folyó finanszírozású rendszerben a nyugdíjasok számának növekedésével a nyugdíjváromány zsugorodik. A helyzeten segíthetne a nagyobb arányú öngondoskodás, az ügyfelek azonban nem állnak sorban a biztosítóknál, hogy nyugdíjbiztosítást köthessenek. Ennek általános viselkedési okai (is) vannak, mert a jövő diszkontálása hiperbolikus. A 20 évvel későbbi helyzetünket szinte egyáltalán nem vesszük számításba.

A piaci alapú megoldások kapcsán kérdéseket vet fel, hogy az állam piaci jelenléte turbó fokozatban van. Miközben a pénztári és biztosítói tartalékok nagy része államkötvényben van, az állam az egyéni fogyasztót is megtalálja a MÁPP, a nyugdíjkötvény és esetlegesen a jóléti alapok révén. Az előadó a hallgatóságra bízta, hogy mindezek alapján milyen következtetéseket vonnak le a jövőre nézve.

A második előadó Czafrangó János közgazdász volt, aki előadását a fenntartható befektetéseknek szentelte. Az előadó azt tekintette fenntarthatónak, ami az 1 sz. ábra szerint a három kör közös halmazát jelenti.
1. ábra: Fenntarthatóság fogalm

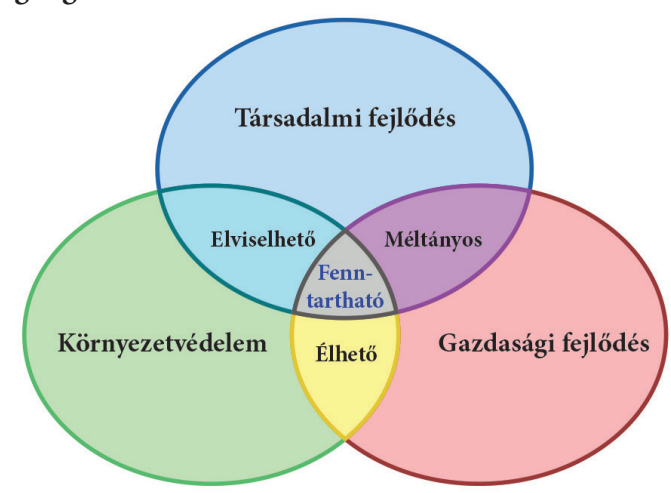

Forrás: Czafrangó János, MABISZ konferencia 2019.

A társadalmi hasznosságú befektetés a társadalmi fókuszú filantrópia és a profitfókuszú hagyományos befektetés között helyezkedik el. Napjaink hármas követelménye ezzel kapcsolatban, hogy

1. amit a környezetbe bocsátunk, az nem haladhatja meg...?

2. amit a környezetből kitermelünk, az nem haladhatja meg...?

3. a nem-megújuló erőforrások elhasználásának a mértéke nem haladhatja meg...?

A fenntartható fejlődés ugyanakkor nem szűkíthető le csupán a környezetvédelmi kérdésekre. Ide tartoznak a társadalmi kockázatok, a szegénység felszámolása, az egyenlőtlenségek csökkentése, a tisztességes munka, a béke, igazságosság, erős intézmények stb. Ezen célok követése fakadhat az adott gazdálkodó szervezet önkéntesen vállalt belső politikájából, lehetnek erre vonatkozóan külső ösztönzők, de egyre inkább számolni kell a jogszabályokkal, melyeknek kényszerítő erejük van. Ez utóbbiról részletesebben a következö kerekasztal beszélt.

Mostanra már megjelent az a réteg, amelyik hajlandó a befektetéseiben is tekintettel lenni a fenntarthatóság szempontjára.

Az élet szekciót is egy kerekasztal-beszélgetés zárta, melynek résztvevői voltak Barczel Nikolett, a Corvinus Egyetem hallgatója, Kovács László, az UNION befektetési igazgatója, Schaub Erika, a Generali igazgatósági tagja és dr. Szebelédi Ferenc, az MNB főosztályvezetője. A moderátor Lencsés Katalin, a MABISZ Életbiztosítási tagozatának vezetője volt. A beszélgetés a fenntartható befektetéseket járta körbe, aminek az apropója egy új európai uniós jogszabálycsomag, mely a fenntartható befektetések elöremozdítását célozza. Ennek kapcsán elvárás, hogy a fenntarthatóság szempontja 
a folyamatok minden fázisában épüljön be a pénzügyi szolgáltatók müködésébe, segítse a tőkeáramlást a fenntarthatónak tekintett befektetések felé, illetve növelje a transzparenciát és a hosszú távú szemléletet. A jogszabály - melyet 2021. márciustól kell alkalmazni - új tájékoztatási kötelezettségeket ír elő a befektetéssel kombinált életbiztosítások esetében.

Első megközelítésben arra keresték a kerekasztal résztvevői a választ, hogy mennyiben igénylik az ügyfelek a fenntarthatósági kockázatokról történő tájékoztatást akkor is, ha ezzel tovább bővül az amúgy sem kicsi tájékoztatási csomag. Abban egyetértés volt, hogy a közvéleményt egyre inkább foglalkoztatja elsősorban a klímavédelem kérdése, és mostanra már megjelent az a réteg, amelyik hajlandó a befektetéseiben is tekintettel lenni a fenntarthatóság szempontjára. Sok befektetési szolgáltató, ezen belül a biztosítók is, már most is kínál fenntarthatóként címzett befektetési alternatívát. Jelenleg ugyanakkor a definíciós rendszer még nem egységes, előfordulhat akár a „zöldrefestés” kockázata is, amikor a termék valójában nem tudja azt, amit állítanak róla. Ezt igyekszik orvosolni az az új EU jogszabály, melynek alapvető célja, hogy egységes európai osztályozási rendszert alakítson ki a gazdasági tevékenységek fenntarthatósági szempontú minősítése tekintetében. A biztosítóknak is ennek mentén kell majd elvégezniük a befektetési eszközök minősítését.

Ennek kapcsán biztosítói oldalról két aggály került megfogalmazásra. A rendelet viszonylag bonyolult és összetett kritériumrendszerhez köti a fenntarthatóság értékelését. Amennyiben a befektetés tárgyát képező cégeknek nem lesz kötelező sztenderdizált módon megadniuk a szükséges adatokat minden befektetési opcióhoz, akkor a pénzügyi szolgáltatóknak egyenként, maguknak kell elvégezniük az értékelést, ami aránytalan terhet jelentene az érintetteknek, felveti a speciális szakértelem és az öszszehasonlíthatóság kérdését. Másik aggály, hogy a közzététel alapjául szolgáló adatok helytállóságáért ki felel, azok ellenőrzése milyen módon történik majd meg.

Nyitott kérdés az is, hogy az új jogszabály alkalmazása mennyiben fogja korlátozni a cégek befektetési politikáját, van-e annak kockázata, hogy a szabályozás veszélyezteti a pénzügyi piacok stabilitását, likviditását, kialakulhatnak-e zöld buborékok vagy befagyott eszközök? Az is megemlítésre került, hogy a Szolvencia II rendszer nem igazán támogatja a biztosítók hosszú távú kötelezettségvállalását, ami a fenntartható befektetéseket is érintheti. A biztosítási szektor az ilyen alkalmakkor mindig elmondja, hogy ez a megközelítés újragondolásra szorul, amihez a kézben lévő SII revízió lehetöséget is kínál.

Áttérve az új tájékoztatási kötelezettségekre, az tehát tovább fogja szaporítani a tájékoztatási csomagot. Nagyon nagy kérdés, hogy ez csak egy újabb dokumentumot fog jelenteni, vagy sikerül azt tartalommal megtölteni. A jogszabályszöveg jelenleg ismert tervezete szerint a tájékoztatás túlságosan bonyolult lesz az ügyfelek számára, kérdés, hogy el tudnak-e majd igazodni benne akár még közvetítői segítséggel is. Párhuzamként a már használatban lévő KID dokumentum került elő, ahol nagyon vegyesek a tapasztalatok, és a problémákat maga az európai jogalkotó is elismerte azzal, hogy elöre hozott, átmeneti revízióval kívánja orvosolni a legnagyobb gondokat.

Az eseményt a szokásos búcsúkoccintás zárta, ahol a konferencia vendégei még tovább folytathatták a gazdag program megvitatását. Az érdeklődők megtalálják az előadások anyagait a MABISZ konferencia honlapján: http://mabiszkonferencia.hu/ 